\title{
Book Review \\ PIECING TOGETHER THE STUDENT SUCCESS PUZZLE: RESEARCH, PROPOSITIONS, AND RECOMMENDATIONS
}

\author{
By Kuh, G. D., Kinzie, J., Buckley, J., Bridges, B., Hayek, J. \\ (ASHE Higher Education Report, Volume 32, Number 5. San Francisco: Jossey-Bass, 2007) \\ Reviewer: Anak Agung M. Sastrawan Putra
}

\begin{abstract}
Fast growing of colleges and universities, tremendous increasing interest in earning bachelor's degree, and complexity problems related to student enrolment and persistence, a single study does not enough effectively explain those problems in the increasingly complex social, economical and cultural issues. Kuh, Kinzie, Buckley, Bridges, Hayek wrote the book based on the extensive literature reviews, especially in the last fifteen years, relating to policies, program, and practices in higher education related to student success. This book provides a wide range of research findings on policies, programs and practices of post secondary education and can be guidance to the college and university management and academic communities in relation to students' success, and useful information for Federal, State and local governments.

The book consists of seven chapters that can be categorized into three major sections focusing on students (conceptual, theoretical perspectives, foundation and student behaviors related to students success), institution conditions, and propositions and recommendations. The book begins with the discussion of the increasing demand of higher education on one hand and low enrolment and achievement of low income and minority students on the other hand. Student's preparation before entering college and rising of college cost are the major reasons that hamper them to enroll and success in college. Through reviewing many studies, Kuh et al. try to find the answers of some questions related to students' characteristics, what factors contribute to students' success and what intervention should be taken to help students' preparation before enrollment and after entering college, and to what groups of students the interventions need to be focused. Following the introduction, Kuh et al. discuss definition and conceptual frame work of students success and propose many indicators related to student success. For the purpose of the report, Kuh et al. define students' success as academic achievement; engagement in educationally purposeful activities; satisfaction; acquisition of desired knowledge, skill, and competencies; persistence; and attainment of educational objectives (p. 10). In the following chapter, Kuh et al. discuss major theoretical perspectives on students' success in college such as sociological, organizational, psychological, cultural, and economic perspectives. Even though no one theoretical perspective can adequately account for all the factors that influence student success in college, Kuh et al. found that students integration is the major factor that relate to students success. Student persistence is a function of dynamic relationships between individual and other actors in the college and the home community. Students most likely to persist are those whose values, norms, and behaviors are already congruent with dominant pattern on campus (p. 15). Difficulties in adapting new social and academic environment found by certain groups of students, such as racial minority and other low income students influence their success in college.

The book then discusses the broader aspects of students' background characteristics, pre college experiences, and enrolment pattern in relation to student success in college. There is a gap of educational level between whites and other racial and ethnic populations (Blacks and Latinos) and
\end{abstract}


between high socioeconomic and low socioeconomic status students. Continuation of the gap would endanger educational attainment in the United States. Providing financial aid will increase low income and minority students' enrolment and attainment in college. However, Kuh et al. found that student's academic preparation is more important than socioeconomic status. College-qualified low-income students who attend four year college have similar performance as middle and high economic status students. Regarding to family education, parents' educational background has a strong impact on student's enrolment and success in college and the strength varies among race or ethnic groups. Latino students were the most represented in the first generation students with more than $40 \%$ of their parents educational background was less than high school compare with less than $20 \%$ of whites. First generation students have a negative impact on students' achievement. Students' whose parents held a bachelor's degree or higher were five times more likely to earns bachelor's degree than were similar first generation students (p.31). First generation students also have lower educational aspiration, less family and social support for attending college, and less knowledge and information about higher education. Academic preparation before attending college is another strong indicator for students' success in college. High school grades are the strongest predictor. Students with rigorous high school courses (completed four year math, science and English) tend to success in college. Less likely to attend high school with calculus may relate to high dropout rate of certain racial, ethnic and low socioeconomic groups such as Latino students.

If in the previous chapter Kuh et al. elaborate students' traits before attending college, in the following chapter they discuss student behaviors, activities, and experiences associated with student success after their enrolment. "Student engagement" is the key term widely used to explain student success after starting college. College grade may the best predictor of student success in college. However, students GPA is associated with students engagement such as spending time for studying, asking question in class, involving in tutorial activities, receiving feedback from faculty, and maintaining high-quality relationship with faculty. Some groups of students are more engage than others, such as women, full time students, students living on campus, students from the same school, international students and students with diversity experiences. First generation and other minority students who receive mentoring and support from faculty and maintain strong relationship with faculty, advisor, and other college personnel were likely experience academic success. Besides faculty members, student peer is the major agent of socialization on campus. Peer support, students involvement in peer tutorial and teaching, working on group project for classes, participating in intramural sports, socializing with student from different racial or ethnic group and other activities involving peer participation have a positive correlation on students success. Student engagement has a different pattern among different groups of students. First generation students, students who live off campus, and transfer students were reported have less engagement.

Even though student individual efforts or engagement are dominant factors influencing students' success, institutional conditions cannot be separated from students' success. Programs, policies, practices, and other institutional conditions have a vital role in facilitating student success. Kuh et al. summarized institution conditions to four overlapping categories: structural and organizational characteristics, program and practices, teaching and learning approaches, and students-centered campus culture. Structural and organizational characteristics such as institutional size, structural diversity, organizational structure, institutional mission, and minority serving institutions are related to student success. Smaller size institution has better students' engagement because of its more favorable faculty-students ratios and smaller classes. A more diverse student body is associated with more positive relation among students. Organizational structure of an 
institution, defined as the patterns and the process of behaviors exhibited by administrators on campus, has some influence on student learning. College with less focused on internal aspects and campuses with collegial ethos have negative impact on students learning. A clear, focused institution mission that related to high standard and expectation for students performance and align with educational policies and programs are generally more effective and efficient. Students attending a minority serving institution such as HBCU (Historically black colleges and universities) receive better peer encouragement to remain enrolled than their counterparts attending PWIs (Predominately white institutions). The book also provides a wide range of programs and practices to help students more engage such as new student adjustment programs, advising, campus residences, learning communities, students success initiatives, teaching learning approach, and student-centered campus cultured.

As a closing chapter, Kuh et al. offer some propositions and recommendations. In relation to students' preparation before entering college, the authors stress the importance to align college and high school, since researchers found that student's success in college begins in grade school. The other proposition emphasizes on the importance of family and community support, especially in increasing the quality of information for students and family who lack adequate information about going to college including financial cost and availability of aid. Since the financial factor is the major obstacle for college-qualified low income students to attend and success in college, the authors propose that financial assistance package should meet students' need and the importance of creating small pockets of emergency fund to address real student need in real time. To help students who start college with two or more risk factors, the authors propose the importance of providing learning supports, early warning system, safety nets, and resources concentration. The next recommendations are related to students' engagement such as making a classroom as a locus of community, suggesting students to live on campus, and involving students in various activities. Other propositions and recommendations are that the institutions should focus on students' success, subscribe a talent development philosophy, and create a student-centered cultured. And the last propositions are that the institution should focus assessment and accountability efforts on what matters on student success.

Since the book was written base on the wide range of studies, difficulties found by the authors in making a confident conclusion when the results of the studies are not focusing on a certain conclusion. For the practical use, especially for the students, parents and other community member interested in students success in college, the book is overwritten and some information are overlapping. However, in general the book is very informative and useful for all college and university stakeholders.

The book provides a wide range of information related to students' success based on a broad and deep of various studies and research. Thus, the book is very useful for them who involved in college and university management such as administrators, faculties, and supporting staff. The book is also important to be read by parents before sending their children to college or university since it provides very useful information related to college preparation and students success in college. Precollege and college students will find many benefits by reading this book as the book provides beneficial information for them in order to be success in college. In relation to college preparation, high school administrators, teachers and school board managements are recommended to read this book. The book is also very informative for them who have an interest in college and university especially in relation to student success. Finally, the book is very useful information for Federal, State, and local government in making plan and implementing programs to help students' success on 
the whole and to provide intervention programs to assist historically underrepresented groups of students, such as first generation students, racial minority and other low income students. 


\section{INDEKS JURNAL PENDIDIKAN TERBUKA DAN JARAK JAUH \\ TAHUN 2013}

analisis data, 10, 38, 53, 54, 56, 61

average differentiation, 1

case test, 80,81

certification, 38

character, 44, 51, 73, 79

character education, 44,73

collaboration, 31, 32, 35, 36

conventional learning, 1

curriculum, 31, 73

data analyze, 53

development research, 62, 64, 72

diskusi online, 22, 24, 26, 27, 28

distance education, 23, 31, 32, 33, 34, 35, 36, 37

dongeng, 44, 50, 51

elementary school, 11, 44

fairy tales, 44

gender, 19, 38, 39, 40, 42, 43

interaksi mahasiswa, 22, 23, 24, 25, 27, 28, 29

jenis kelamin, 38, 41

karakter, 40, 44, 45, 46, 47, 48, 49, 50, 51, 73, 74, 75, 76, 78, 79

keaktifan, 60

kemampuan komunikasi matematis, 1, 81, 82, 83, 84, 85, 87

kinerja, 11, 13, 14, 15, 17, 18, 19, 20, 21

komunikasi matematika, 6, 9, 80, 81, 86, 87

konsep bilangan bulat, 11, 13, 14, 15, 16, 17, 18, 19

kurikulum, 20, 31, 51, 62, 73, 77, 87

lembar kerja mahasiswa, 53

lessons, 73

macromedia flash, 62, 64, 65, 70

masalah, 2, 3, 4, 9, 13, 20, 22, 23, 26, 27, 28, 46, 49, 53, 54, 55, 56, 59, 60, 74, 78, 80, 81, 82, 83, $84,86,87$

mathematical communication, 1, 80, 81

mathematical communication ability, 1

MEAs strategy, 1

modul, 11, 12, 13, 14, 15, 17, 18, 19, 24, 26, 27, 31, 55

motivasi, 11, 13, 14, 16, 17, 18, 19, 20, 23, 40, 42, 63, 75, 76, 85

motivation, 11, 24

online discussion, 22, 29

online tutorial, 22, 35 
pembelajaran, 1, 2, 3, 5, 6, 7, 8, 9, 10, 12, 13, 14, 20, 23, 24, 26, 27, 28, 30, 31, 39, 41, 42, 43, 49, $50,54,60,61,62,63,64,65,66,67,68,69,70,71,72,73,76,77,78,79,80,81,82,83$, $84,85,86,87$

pembelajaran konvensional, 1, 2, 5, 6, 7, 8, 9

pemecahan masalah, 20, 53, 80, 81, 82, 83, 84, 85, 86, 87

pemecahan masalah pendekatan, 80

pendidikan karakter, 44, 45, 46, 47, 48, 49, 50, 51, 73, 75, 76, 79

performance, 11, 27, 29, 38, 98, 99

prestasi belajar, 16, 19, 20, 38, 39, 41, 42

problem solving, 53, 61, 80, 81

problem solving approach, 80, 81

problems, 36, 53, 80, 97

projects, 53

proyek, 53, 54, 55, 56, 59, 60

rata-rata diferensiasi, 1

segitiga, $62,63,64,65,66,67,68,70,71$

sekolah dasar, 44, 81, 82

sertifikasi guru, 38, 39, 41, 42, 43

strategi MEAs, 1, 2, 3, 10

student interaction, 22

student performance, 38

triangular, 62

tutorial online, 20, 22, 23, 24, 25, 26, 28, 29

uji kasus, 80

UT, 12, 13, 15, 16, 18, 20, 21, 22, 24, 29, 31, 35, 36, 38

whole number concept, 11 


\title{
INDEKS PENULIS JURNAL PENDIDIKAN TERBUKA DAN JARAK JAUH \\ TAHUN 2013
}

\author{
Endang Wahyuningrum \\ Dadang Lorida \\ Tatang Herman \\ Yusuf Hartono \\ Didi Permana \\ Meilani Safitri \\ Sri Sukarti \\ Wahyudin \\ Herawati \\ Herman \\ Somakim \\ Sumarno \\ Karlimah \\ Dania Fuji Lestari \\ Jackson Pasini Mairing \\ A.A.M. Sastrawan Putra \\ Sylvia Primulawati Soetantyo
}




\title{
INDEKS PENYUNTING JURNAL PENDIDIKAN TERBUKA DAN JARAK JAUH
}

\section{TAHUN 2013}

\author{
Sandra Sukmaning Aji \\ Udin S. Winataputra \\ Wahyuni Kadarko \\ I.G.A.K. Wardani \\ Agus Santoso \\ Purwanto \\ Suciati \\ Herman \\ Rustam \\ Amalia S \\ Jan Hotman \\ Benny A. Pribadi \\ Tuti Purwaningsih \\ Lidwina Sri Ardiasih \\ Rahayu Dwi Riyanti
}

